\title{
THE DEGREE OF COMPLIANCE BASED ON EXCISE DUTIES IN ROMANIA BETWEEN 2002 AND 2015
}

\section{Silvia Paula Todor Ph.D. student}

Faculty of Finance

The Bucharest University of Economic Studies, Romania e-mail: silviapaulatodor@gmail.com

Rodica Ghiur PhD student Faculty of Finance

The Bucharest University of Economic Studies, Romania e-mail: ghiur.rodica@gmail.com

\section{Petre Brezeanu Ph.D. Professor} Faculty of Finance

The Bucharest University of Economic Studies, Romania e-mail: brezeanupetre@yahoo.com

Florin Dumiter Ph.D. Professor

Faculty of Economics, Engineering and Informatics, Vasile Goldiş Western University of Arad, Romania e-mail: fdumiter@yahoo.com

\section{Marius Boiță Ph.D. Associate Professor}

Faculty of Economics, Engineering and Informatics, Vasile Goldiș Western University of Arad, Romania e-mail: bmarius1963@yahoo.com

(Received April 2017; Accepted July 2017)

\begin{abstract}
The fiscal policy is an instrument that collects resources for the state budget necessary to perform state functions; stabilize the economy; regulation of the economy and recovery growth. The most important instruments are taxes and taxpayers. Since 1989, with the transition to a market economy, a special tax policy has been known by excise taxes. Analyzing the case of Romania and the evolution of excise duties (hereinafter ED) conformity we created some regressions that illustrate the ED correlation in Romania between 2002 and 2015. The methodology used: three unifactorial regression models showing how ED impacts economic indicators such as GDP, power purchase expressed through the net annual average salary, and household final consumption expenditure. Moreover, each model has been tested and verified using statistic tests to give reliable results. In a first stage, we analyzed the correlation between GDP and consumption as endogen variable and ED, then we created another model that we kept ED as an independent variable, but we changed the dependent variable using the purchasing power as a dependent variable. Because according to the used tests we demonstrated that correlation coefficients are significant, we proceeded to explain them starting from fiscal policy and economic reality, own of these analyzed 14 years. In conclusion we highlighted below as
\end{abstract}


Todor S.P., Ghiur R., Brezeanu P., Dumiter F., Boiță M. (2017)

The degree of compliance based on excise duties in Romania between 2002 and 2015

the ED depends on GDP and consumption and the purchasing power can influence the ED. For future discussion and studies we intend to compare the results with other countries in different geographic areas in Europe

Keywords: Tax conformity, regression, evolution, excise duties, fiscal policy.

JEL: G 40, H 30.

\section{Introduction}

Excise duties are the consumer charges set by the legislation in force by which any consumer (a natural or legal person) owes the state budget for consumption of products subject to this tax, whether it is domestic production or import. The regulations in force very clearly define excise duties and classify them, of course also detailing the situations in which they are exempt from payment.

Taking into account the competitive market mechanisms and the tendency of modern states to intervene in the economy with tax, we can easily notice what a significant role the taxes play, whether we refer to direct or indirect ones, being used as a lever of economic policy through which we can Accentuate or brake certain areas of activity, and increase or curb consumption in a particular category of goods or services. Due to taxes and taxes, financial incomes are accumulated at the state's disposal, which is why the fiscal policy of any country is very important and clear and uninterruptible regulation is needed. The state through this fiscal system accumulates resources to the state budget, which will then finance its expenses in order to carry out its duties. In practice, there are a number of taxes and fees that can be categorized by content and form

The excise duty regime applied to other products shall be determined by the competent authorities of the Community countries, provided that their taxation does not require a border control. Those authorities are entitled to charge taxes (other than value added tax) and service charges.

Special consumption taxes or excise duties are applicable to products that are consumed in high quantities and can not be replaced by other products of the same kind. Thus, consumption is approximately linear without large oscillations, so if the level of excises remains roughly the same and the fiscal yield remains constant. We can easily as a result of the tests that excise duties have an impact on gross domestic product and implicitly on final consumption but not on a very large weight because they are by nature not applicable to a large category of products and implicitly to consumers such as VAT.

\section{Research methodology}

According to the abstract, this article aims to highlight the impact of voluntary compliance from the excise tax perspective. In practice, we want to outline how the amount of revenue from the collection of these taxes affects, on the one hand, gross

2 DE GRUYTER Studia Universitatis "Vasile Goldis" Arad. Economics Series Vol 27 Issue 3/2017 OPEN ISSN: 1584-2339; (online) ISSN: 2285-3065 
Todor S.P., Ghiur R., Brezeanu P., Dumiter F., Boiță M. (2017)

The degree of compliance based on excise duties in Romania between 2002 and 2015

domestic product (GDP) and, on the other hand, final consumption. Another aspect that we propose through the article is to identify how purchasing power explains the variation in excise duties. In this respect, we will proceed to the construction of 3 single-factor models, in 2 of them the excises (meaning the revenues collected in the budget from their collection) constituted the independent variable, and in the third variable dependent on purchasing power This third model is a reversed form precisely because, starting from the fact that in most cases we are discussing an inelastic demand for excisable products in relation to the price, we wanted to see how purchasing power over a period of 14 Do not influence the revenue from excise collection, just as the different purchasing power infuses the consumption of excisable products and implicitly the revenues collected from the budget from this consumption tax. In order to achieve these regressions, we used the Eviews software platform, the 9th version. Regarding the veracity of the data, we mention that these have been taken from the European Commission website as follows:

\begin{tabular}{c|cccc} 
& îA & $\begin{array}{c}\text { Table no.1 } \\
\text { GDP }\end{array}$ & C* & PP* \\
\hline $\mathbf{2 0 0 2}$ & 16 & 48500 & 33143 & 124 \\
\hline $\mathbf{2 0 0 3}$ & 24 & 52600 & 34622 & 130 \\
\hline $\mathbf{2 0 0 4}$ & 223 & 60800 & 41744 & 147 \\
\hline $\mathbf{2 0 0 5}$ & 176 & 79500 & 54994 & 204 \\
\hline $\mathbf{2 0 0 6}$ & 226 & 97700 & 66881 & 245 \\
\hline $\mathbf{2 0 0 7}$ & 90 & 123700 & 83257 & 285 \\
\hline $\mathbf{2 0 0 8}$ & 50 & 139700 & 88671 & 348 \\
\hline $\mathbf{2 0 0 9}$ & 53 & 118300 & 72488 & 326 \\
\hline $\mathbf{2 0 1 0}$ & 325 & 124100 & 78708 & 334 \\
\hline $\mathbf{2 0 1 1}$ & 480 & 131500 & 82713 & 348 \\
\hline $\mathbf{2 0 1 2}$ & 482 & 133900 & 84558 & 347 \\
\hline $\mathbf{2 0 1 3}$ & 403 & 144700 & 88238 & 367 \\
\hline $\mathbf{2 0 1 4}$ & 421 & 150800 & 92990 & 384 \\
\hline $\mathbf{2 0 1 5}$ & 489 & 159000 & 97693 & 416
\end{tabular}

*ÎA - the excise tax

*GDP - Gross domestic power - C - consumption and PP - power purchase. All values in the table are amounts expressed in millions of Euros.

Because all three models that we will build next are single regression linear regression models, we will present some general aspects of linear regression. A first aspect looks at its form:, $\mathrm{i}=1,2, \ldots, \mathrm{n}$. A second aspect is related to the data by which the statistics generally operate, so only estimates of maximum veracity are used in statistics, which can only be obtained if certain conditions are 
Todor S.P., Ghiur R., Brezeanu P., Dumiter F., Boiță M. (2017)

The degree of compliance based on excise duties in Romania between 2002 and 2015

cumulatively met. These conditions are in fact those assumptions that are associated with each regression model in order to obtain certain properties for model parameter estimators. Therefore, as we are in the context of a classical linear regression model, we will present the six standard assumptions: The figure is linear and has the following form: $\quad y i=\mathrm{a}+\beta x_{i}+\Sigma_{i}, i=1,2, \ldots, \mathrm{n}$.

1. Random errors are of average zero (because random error is regarded as the sum of random factors with different signs, it is admitted that these unregistered factors will not produce an average effect on the dependent variable): $\mathrm{E}\left(\varepsilon_{i}\right)=0, i=1,2, \ldots, n$.

Homoscedasticitatea of random errors (according to which the link between the dependent and independent variable is relatively stable): $\operatorname{Var}\left(\varepsilon_{i}\right)=\sigma_{X}^{2}=\sigma^{2}, i=1$, $2, \ldots \ldots \ldots n$.

2. Random errors are not correlated (according to this hypothesis by randomly choosing two errors these are not correlated): $\operatorname{cov}\left(\varepsilon_{i}, \varepsilon_{j}\right)=0$, pentru $i \neq \mathrm{j}$.

Registers and random errors are not correlated (random errors do not depend on explanatory variables): $\operatorname{cov}\left(\varepsilon_{i}, x_{i}\right)=0$, pentru $(\forall)$ i și $\mathrm{j}$. Random errors are normally distributed $(\forall)$ linear function of normally distributed distributions is normally distributed; Central Limit Theorem): $\quad \Sigma_{i} \infty \mathrm{N}\left(0, \sigma^{2}\right)$ (Damalan, 2016).

So we will still predict model parameters using the smallest squares method (MCMMP). We will test the models so obtained using the Student test (Penu, 2016), we will also see to what extent the resulting coefficients are significant and what is the likelihood of accepting the alternative hypothesis. Finally, we will try to analyze the time series from three perspectives: the distribution asymmetry over its media, the height of series distribution and stationarity.

\section{Results and discussion}

\subsection{The impact of excise revenue on gross domestic product}

Although intuitively we can assume that the average of the dependent variable depends on a linear relation to the average of the independent variable (Anghelache, Pagliacci and Prodan, 2013), however, from diligence reasoning, in order to identify the typology of the regression function, we will graphically represent the pairs of points The amounts representing the amounts collected from the excise budget and the GDP. 
Todor S.P., Ghiur R., Brezeanu P., Dumiter F., Boiță M. (2017)

The degree of compliance based on excise duties in Romania between 2002 and 2015

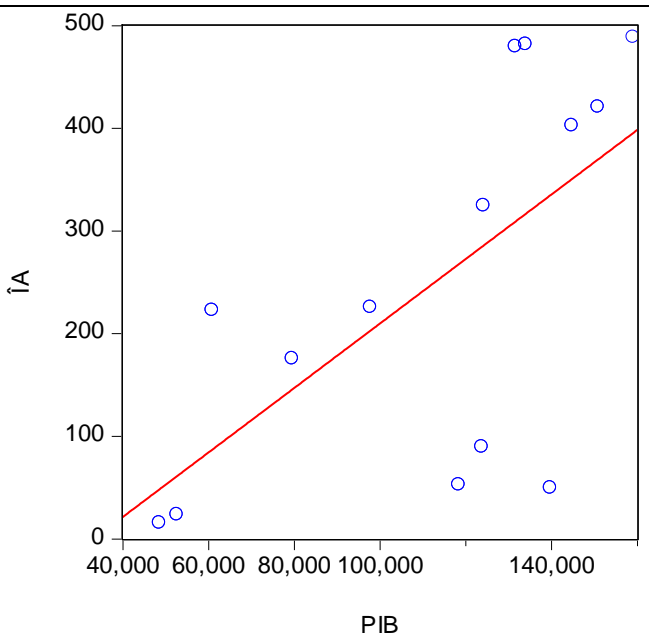

Diagram no. 1

So, by analyzing the point cloud or the right scattering diagram, we can deduce that the phenomenon can be described by a linear regression linear model (Anghelache, Anghelache and all 2012). Using the Eviews platform we proceeded to estimate the parameters as can be seen from the table below:

Table no. 2

\begin{tabular}{lrlll}
\hline \hline \multicolumn{1}{c}{ Variable } & Coefficient & Std. Error & Statistic t & Prob. \\
\hline \hline \multicolumn{1}{c}{ IA } & $\mathbf{1 3 0 . 0 5 3 3}$ & 45.17341 & $\mathbf{2 . 8 7 8 9 8 0}$ & $\mathbf{0 . 0 1 3 9}$ \\
C & $\mathbf{7 9 6 4 8 . 2 5}$ & 13729.10 & $\mathbf{5 . 8 0 1 4 2 0}$ & $\mathbf{0 . 0 0 0 1}$ \\
\hline \hline R-squared & 0.408533 & Mean dependent var & 111771.4 \\
Adjusted R-squared & 0.359244 & S.D. dependent var & 37391.82 \\
S.E. of regression & 29931.13 & Akaike info criterion & 23.58275 \\
Sum squared resid & $1.08 E+10$ & Schwarz criterion & 23.67404 \\
Log likelihood & -163.0792 & Hannan-Quinn critter. & 23.57430 \\
F-statistic & 8.288526 & Durbin-Watson stat & 0.503052 \\
Prob(F-statistic) & 0.013857 & & \\
\hline \hline
\end{tabular}

Replacing the values thus obtained in the form of the linear function, as it was presented above, we obtain: $\mathrm{y}_{\mathrm{i}}=\alpha+\beta x_{i}+\Sigma_{i} \Rightarrow \mathrm{PIB}=130.0533 * \hat{\mathrm{IA}}+79648.25$. 
Todor S.P., Ghiur R., Brezeanu P., Dumiter F., Boiță M. (2017)

The degree of compliance based on excise duties in Romania between 2002 and 2015

Thus, a first observation is that there is a direct link between the two variables, which implies that the increase of the excise tax revenues automatically involves GDP growth, which is quite logical, we can not say that this link would be very strong Analyzing its values R şi R2. According to these indicators, the change in GDP is explained in a small percentage by the change in excise receipts. Basically, according to R, the link between the two variables is $40.85 \%$, and is appropriate R2 The GDP variation is explained in a proportion of $35.92 \%$ of the proceeds of this tax. Moreover, assuming ad absurdum that excise goods disappeared on our market and implicitly the tax collected from them, GDP would be $130.0533 * 0+79648.25$ $=79648.25$. The fact that GDP variation is explained in such a small percentage by the variation in excise receipts can also be explained by the role of product excise, one of which is even discouraging consumption. But when you discourage consumption of excisable products (by analyzing the situation in the state's perspective), it is inappropriate to want an increase in excise tax revenues and a strong link between them and GDP, because it would go against logic, so the model we built Reflects an existing economic reality (so the objective that the state promotes a policy of hindering consumption reduces the achievement of another objective of the statute - ensuring budget revenues) and a sustainable logic in this respect. As shown above, we wanted to use the Student test for testing. According to the table above $\mathrm{t}_{\mathrm{I} A}=2.878980$ și $\mathrm{c}_{\text {onstants }}=5.801420, \mathrm{~s}_{\text {table }}=\mathrm{t}_{0,05 ; 14 ;}=1,761$, Where we deduce that tricycles is lower than both $\mathrm{tC}$ and $\mathrm{tC}$, therefore the coefficients calculated from the unifactorial model are significant. The above probabilities show to what extent the latter are significant. Given that in both cases we disagree with values below 0.05 , we infer that we can accept the alternative hypothesis for both coefficients with a probability of $95 \%$, stating that the two coefficients are significant.

\subsection{The impact of revenue from excise duties on household final consumption expenditure}

Next, we will try to outline how the tax revenues influence another macroeconomic indicator, namely household final consumption expenditure (hereinafter and final consumption or CFP). Like the previous subchapter we will start from the point cloud chart analysis that represents these two series to ensure that we have a single factor linear model.

Therefore, according to the scatter plot no. 2 we can say that we are in the presence of a linear regression, aspect that allows us to pass on parameter estimation with the software and testing it, as can be seen from table no. 3 . 
Todor S.P., Ghiur R., Brezeanu P., Dumiter F., Boiță M. (2017)

The degree of compliance based on excise duties in Romania between 2002 and 2015

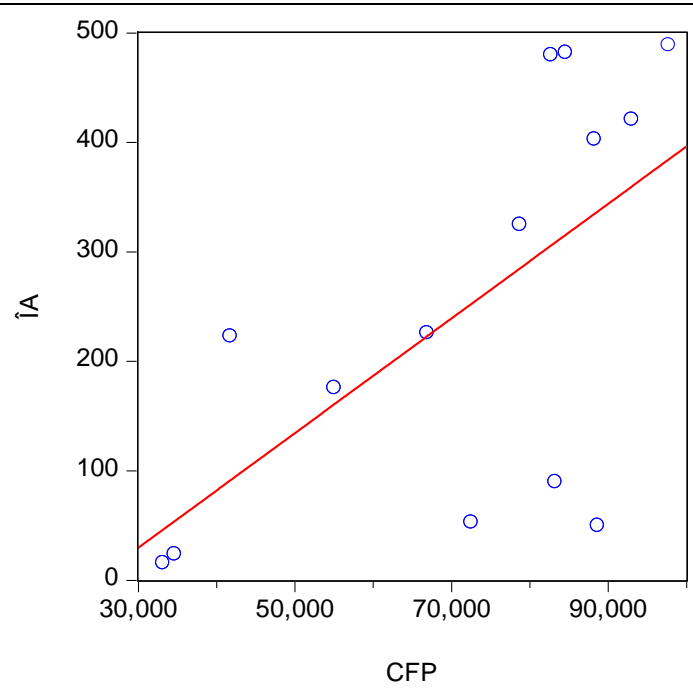

Diagram no. 2

Table no. 3

\begin{tabular}{lrllr}
\hline \hline \multicolumn{1}{c}{ Variable } & Coefficient & Std. Error & Statistic T & Prob. \\
\hline \multicolumn{1}{c}{ IA } & $\mathbf{7 4 . 2 1 0 7 3}$ & 26.86774 & 2.762076 & 0.0172 \\
\multicolumn{1}{c}{ C } & $\mathbf{5 3 1 4 8 . 5 2}$ & 8165.639 & 6.508801 & 0.0000 \\
\hline \hline R-squared & 0.388662 & Mean dependent var & 71478.57 \\
Adjusted R-squared & 0.337717 & S.D. dependent var & 21875.07 \\
S.E. of regression & 17802.10 & Akaike info criterion & 22.54358 \\
Sum squared resid & $3.80 E+09$ & Schwarz criterion & 22.63488 \\
Log likelihood & -155.8051 & Hannan-Quinn criter. & 22.53513 \\
F-statistic & 7.629064 & Durbin-Watson stat & 0.474163 \\
Prob(F-statistic) & 0.017213 & & \\
\hline \hline
\end{tabular}

We will replace and in this case the values thus obtained in the form of the linear regression, as it was presented above, resulting: $\mathrm{y}_{\mathrm{i}}=\alpha+\beta x_{i}+\Sigma_{i} \Rightarrow \mathrm{CFP}=$ $74.21073 * \hat{\mathrm{IA}}+53148.52$. Thus, a first observation and in this case is that between the two variables is a direct link, which implies that the increase of the excise tax revenues automatically involves the increase of the consumption, which in the first phase may seem inappropriate in relation to the role of the excise duties, given that these (excise duties) are meant to discourage consumption, but an another 
Todor S.P., Ghiur R., Brezeanu P., Dumiter F., Boiță M. (2017)

The degree of compliance based on excise duties in Romania between 2002 and 2015

particularity of excisable products is that they "enjoy" of the elasticity greater than 1 of their demand in relation to the population's income, which may explain why the increase of excise duty revenue and implicitly excise duty has not resulted in a decrease in consumption. However, like the previous model, we can not say that this link would be a very strong one by analyzing the values of $R$ and $R^{2}$. According to these indicators the variation in consumption is explained in a small percentage by the variation in revenues from excises. Practical, according to $\mathrm{R}$, the link between the two variables is about $38.86 \%$, and according to $\mathrm{R}^{2}$, the consumption variation is explained in the proportion of $33.77 \%$ of the receipts of this tax. Given that excise goods represent only a limited range of products by reference to the whole volume of products in the civil circuit, it is obvious that, as shown by the following equation: $74.21073 * 0+53148.52=53148.52$, even though excisable products would no be marketed and the state would not charge this tax, the value of the consumption would be positive. And for this model, we will use the Student test to test the model. According to the above table $\mathrm{t}_{\mathrm{IA}}=$ 2.762076 and $\mathrm{c}_{\text {onstants }}=6.508801, \mathrm{t}_{\text {table }}=\mathrm{t}_{0,05 ; 14 ;}=1,761$, we deduce that the critical value is smaller than $\mathrm{t}_{\mathrm{I} \mathrm{A}}$ and $\mathrm{c}_{\text {onstants, }}$, therefore the coefficients calculated from the unifactorial model are significant. The above probabilities show the percentage in which the coefficients are significant. Considering that in both cases we have values below 0.05 , we deduce that we can accept the alternative hypothesis for both coefficients with a probability of $95 \%$, stating that the two coefficients are significant.

\subsection{Impact of purchasing power on state budget revenues from excise duties} In the beginning of this third chapter, we have specified that this unifactorial model has another form, an inverted one, not by the regression model, but by the fact that in this scenario we intended to explain the excise receipts through the purchasing power (hereinafter and PC) and not explain a macroeconomic indicator like PC by excises, practically in this third unifactorial model the dependent variable model will be represented by the excise receipts. Before we proceed to model estimation, we note that purchasing power has not been found by us on national or international portals which collect and process data in its own form. The purchasing power is the generic name that we (the authors of this article) attributed to a series of data that defines the annual average of net earnings over the last 14 years. So, this model will show how the net average earnings influence the consumption of excisable products and implicitly excise tax revenues to the state budget. 


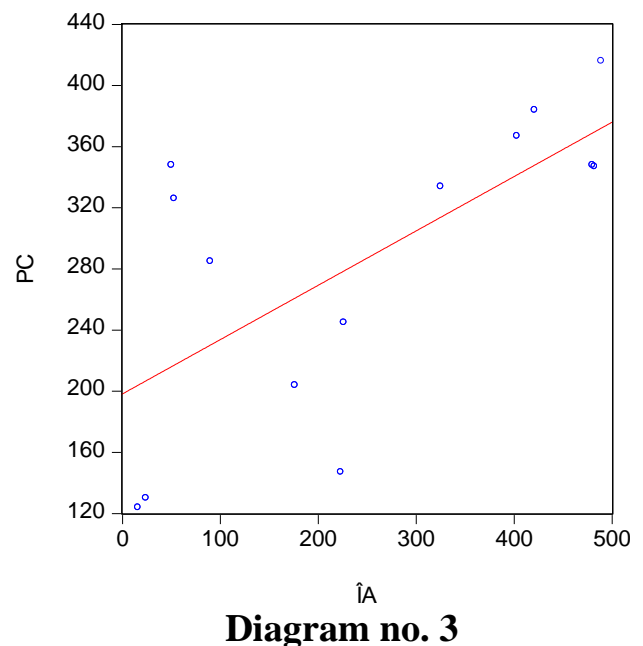

So, and in this third case, we can say that we are in the presence of a linear regression, which allows us to pass on parameter estimation with software and testing it, as can be seen from the following table:

Table no. 4

\begin{tabular}{lrlll}
\hline \hline \multicolumn{1}{c}{ Variable } & Coefficient & Std. Error & Statistic t & Prob. \\
\hline \hline \multicolumn{1}{c}{ PC } & $\mathbf{1 . 2 3 2 0 7 2}$ & 0.402845 & 3.058424 & 0.0099 \\
\multicolumn{1}{c}{ C } & $\mathbf{- 1 0 5 . 4 6 0 7}$ & 121.4469 & -0.868369 & 0.4022 \\
\hline \hline R-squared & 0.438043 & Mean dependent var & 247.0000 \\
Adjusted R-squared & 0.391214 & S.D. dependent var & 183.7674 \\
S.E. of regression & 143.3841 & Akaike info criterion & 12.90049 \\
Sum squared resid & 246708.0 & Schwarz criterion & 12.99179 \\
Log likelihood & -88.30346 & Hannan-Quinn criter. & 12.89204 \\
F-statistic & 9.353958 & Durbin-Watson stat & 0.785499 \\
Prob(F-statistic) & 0.009928 & & \\
\hline \hline
\end{tabular}

Substituting and in this case the resulted values in the form of the linear regression, as presented above, we obtain: $\mathrm{y}_{\mathrm{i}}=\alpha+\beta x_{i}+\Sigma_{i} \Rightarrow \hat{\mathrm{IA}}=1.232072 * \mathrm{PC}$ 105.4607. Thus, a first observation and in this case is between these two variables 
Todor S.P., Ghiur R., Brezeanu P., Dumiter F., Boiță M. (2017)

The degree of compliance based on excise duties in Romania between 2002 and 2015

is a direct link, which implies that the increase in average earnings automatically implies an increase in the consumption of excisable products and implicitly an increase of revenues to the state budget from excises, an intuitive aspect if we remember that for these products, demand is inelastic, applying a fortiori argument, all the more so revenue increases, the population will be tempted to acquire such products (the more obvious aspect in the case of luxury products). However, like previous models, we can not say that this link would be a very strong one by analyzing the values of $R$ and $R^{2}$. According to these indicators, the variation in excise receipts is explained in a small percentage by the average earnings variation, which is explained by the inelasticity of demand. So, according to $\mathrm{R}$, the link between the two variables is approximately $43.80 \%$, and according to $\mathrm{R}^{2}$ the variance of IA (receipts form excise duties) is explained in the ratio of $39.12 \%$ of purchasing power. And for this model we will use the Student test to test the model. According to the table above $\mathrm{t}_{\mathrm{PC}}=3.058424$ and $\mathrm{c}_{\text {onstants }}=-$ $0.868369, \mathrm{t}_{\text {table }}=\mathrm{t}_{0.05 ; 14 ;}=1.761$, so we deduce that critical value is only smaller than $t_{\mathrm{PC}}$, this is the only significant coefficient, aspect also indicated by the probability value much below 0.05 , which shows that we can accept the alternative hypothesis only for the purchasing power coefficient with a probability of $95 \%$.

As we mention above, a part of the analysis is about the way in which the analyzed series are presented in time. The first two perspectives relate to the series distribution asymmetry over its own average and the height of the distribution. In this sense we will build the histograms for all four time series, and according to the Skewness and Kurtosis tests, we will make a comparative analysis of these. The following 4 histograms are built using the same software platform:
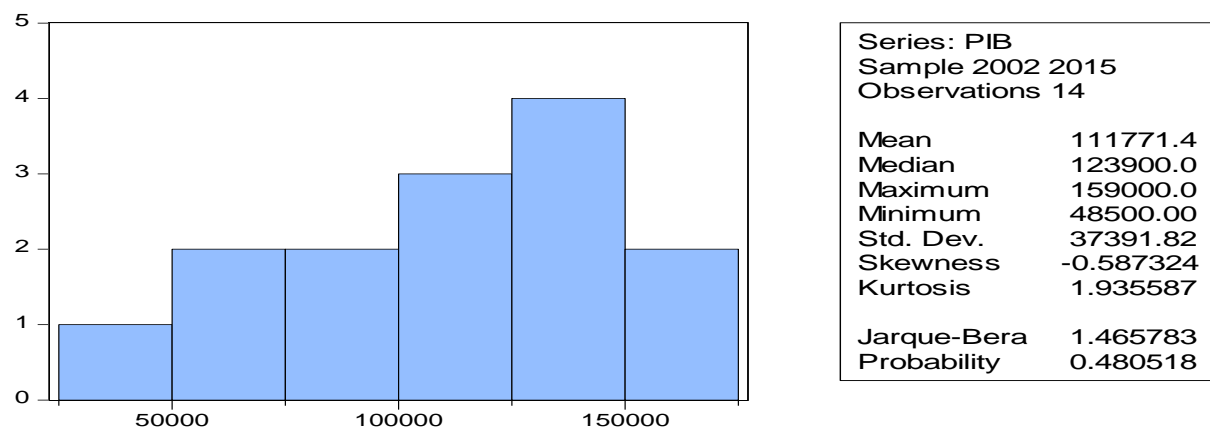
0.480518

Graphic no. 1 The histogram of GDP (hereinafter and PIB)

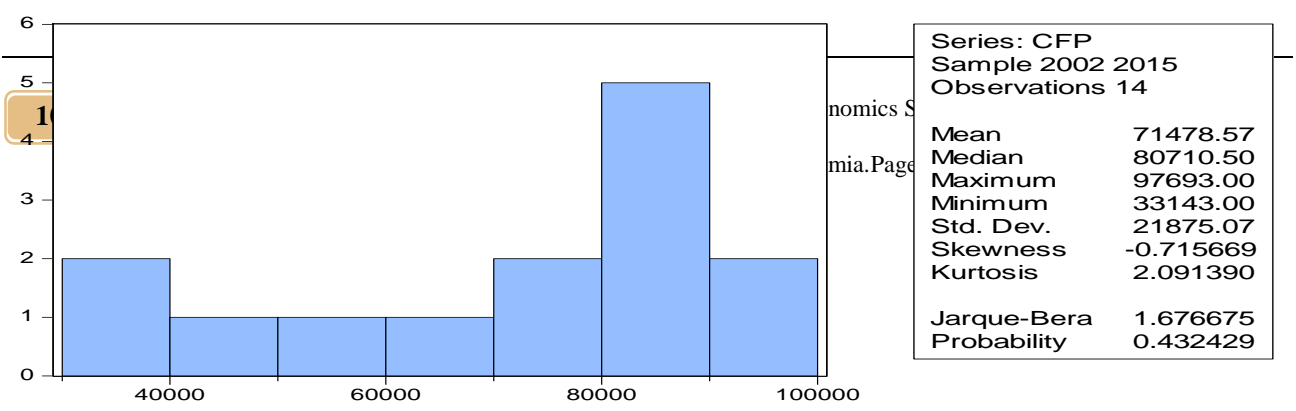




\section{Graphic no. 2 The histogram of household final consumption}

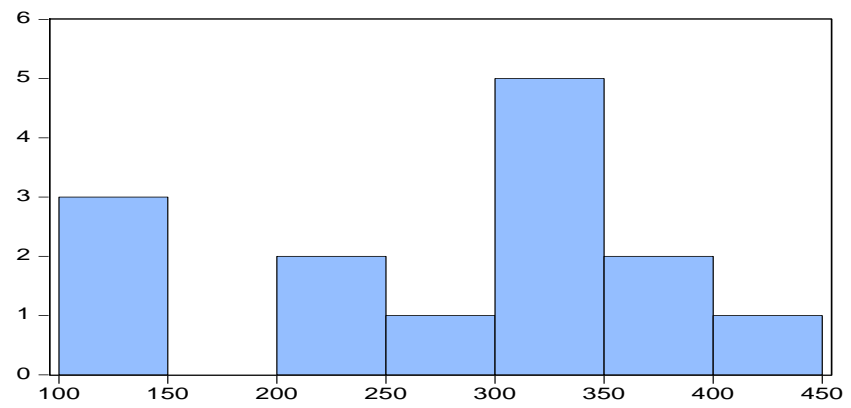

\begin{tabular}{|ll|}
\hline \multicolumn{2}{|l|}{ Series: PC } \\
Sample 2002 2015 \\
Observations & 14 \\
Mean & 286.0714 \\
Median & 330.0000 \\
Maximum & 416.0000 \\
Minimum & 124.0000 \\
Std. Dev. & 98.71674 \\
Skewness & -0.567018 \\
Kurtosis & 1.898559 \\
Jarque-Bera & 1.457872 \\
Probability & 0.482422 \\
\hline
\end{tabular}

Graphic no. 3 The histogram of purchasing power

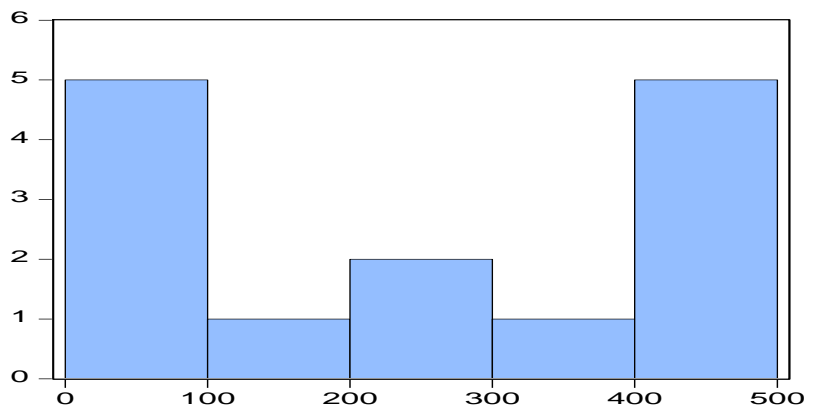

\begin{tabular}{ll}
\hline Series: IA & \\
Sample 2002 2015 \\
Observations 14 \\
Mean & 247.0000 \\
Median & 224.5000 \\
Maximum & 489.0000 \\
Minimum & 16.00000 \\
Std. Dev. & 183.7674 \\
Skewness & 0.086505 \\
Kurtosis & 1.441819 \\
& \\
Jarque-Bera & 1.433752 \\
Probability & 0.488275 \\
\hline
\end{tabular}

Graphic no. 4 The histogram of receipts from excises

According to the Skewness test, a test that indicates the deviation of empirical distribution by reference to the symmetric distribution around the mean, in the case of GDP, consumption and purchasing power, we are in a situation where, given that the values are less than zero, the distribution is tilted to the right, with more extreme values to the left. As respects excise duties, the value of 0.086505 indicates that the distribution is tilted to the left, with many extreme values to the right. According to the Kurtosis test, a test indicating the degree of flattening or sharpening of a distribution, given that for all four series the test indicates values less than 3 , we are in the situation of platykurtic distribution, being more flat than 
Todor S.P., Ghiur R., Brezeanu P., Dumiter F., Boiță M. (2017)

The degree of compliance based on excise duties in Romania between 2002 and 2015

the normal distribution with dispersed values on a larger interval around the average. Therefore, for all four time series, the probability of occurrence of extreme values is lower than if they had a normal distribution.

The last proposed perspective of analysis for these article remains testing the stationary of the series. We will test the stationary with the Dickey Fuller Test, as shown in the following 4 tables.

Table no. 5 .

\begin{tabular}{cccc}
\hline \hline & Statistic t & Prob. $^{*}$ \\
\hline \hline \multicolumn{2}{c}{ Augmented Dickey-Fuller test statistic } & $\mathbf{- 1 . 2 3 9 2 5 7}$ & 0.6230 \\
\hline Test critical values: & 1\% level & -4.057910 & \\
& 5\% level & -3.119910 & \\
& $10 \%$ level & -2.701103 & \\
\hline \hline
\end{tabular}

*MacKinnon (1996) one-sided p-values.

Table no. 6.

\begin{tabular}{cccc}
\hline \hline & & Statistic t & Prob. $^{*}$ \\
\hline \hline \multicolumn{2}{c}{ Augmented Dickey-Fuller test statistic } & $\mathbf{- 1 . 4 1 8 3 6 6}$ & 0.5407 \\
\hline Test critical values: & 1\% level & -4.057910 & \\
& 5\% level & -3.119910 & \\
& $10 \%$ level & -2.701103 & \\
\hline \hline
\end{tabular}

*MacKinnon (1996) one-sided p-values.

Table no. 7.

\begin{tabular}{cccc}
\hline \hline & & & \\
& Statistic t & Prob. $^{*}$ \\
\hline \hline \multicolumn{2}{c}{ Augmented Dickey-Fuller test statistic } & $\mathbf{- 1 . 0 8 7 5 1 6}$ & 0.6864 \\
\hline Test critical values: & 1\% level & -4.057910 & \\
& 5\% level & -3.119910 & \\
& $10 \%$ level & -2.701103 & \\
\hline \hline
\end{tabular}

*MacKinnon (1996) one-sided p-values.

Table no. 8

\begin{tabular}{cccc}
\hline \hline & & Statistic t & Prob. $^{*}$ \\
\hline \hline \multicolumn{2}{c}{ Augmented Dickey-Fuller test statistic } & $\mathbf{- 1 . 0 8 5 3 6 2}$ & 0.6873 \\
\hline Test critical values: & 1\% level & -4.057910 & \\
& 5\% level & -3.119910 & \\
& $10 \%$ level & -2.701103 & \\
\hline \hline
\end{tabular}

*MacKinnon (1996) one-sided p-values.

Because the values of statistical $t$ are much lower than $t_{\text {tabel }}$ (critical value - 1,761), we are in the situation of rejecting the null hypothesis for all four time series,

12 DE GRUYTER OPEN
Studia Universitatis "Vasile Goldis" Arad. Economics Series Vol 27 Issue 3/2017 SSN: 1584-2339; (online) ISSN: $2285-3065$

Web: publicatii.uvvg.ro/index.php/studiaeconomia.Pages 1 - 14 
resulting that each of them are stationary series over time. Therefore, the stationary of the time series shows that if there was a shock on these series, it would absorb over time and would not be one with permanent effects.

\section{Conclusions and discussion}

By this article has achieved the main objective of highlighting and impacting voluntary compliance from excise duties perspective. In the future we are going to compare the result with other countries with a developed economy and with countries with emergent economy. Thus, we have succeeded to demonstrate that revenues collected from excise duties to the state budget are influenced by final consumption and purchasing power. Of course, excise taxes have a small contribution to a nation's budget revenue and the overall impact is not very high, but we have managed to establish a connection between the variables. The increase in average earnings automatically implies an increase in the consumption of excisable products and budget revenues, intuitive aspect if we start at the premise that the demand for these products is inelastic, especially if revenue increases, the population it will be tempting to buy such products (the more obvious in the case of luxury products). However, as a general conclusion we can not say that this link would be a very strong one.

\section{Selective bibliography}

1. Anghelache, C., Pagliacci, M, Prodan, L., ,,Model de analiză macroeconomică bazat pe funcţia de regresie", Romanian Journal of Statistics no. 1/2013.

2. Anghelache, G.-C., Anghelache C., Prodan, L., Dumitrescu, D., Soare, D., V., „Elemente teoretice privind utilizarea modelului econometric de regresie multifactorială”, Romanian Statistical Review Trim III / 2012- Supplement.

3. Dervis, K., De Melo, J. and Robinson, S. (1982). "General Equilibrium Models for Development Policy" New York, Cambridge University Press Devarajan, S., Lewis, J.D. and Robinson, S. (1994). "Getting the Model Right: The General Equilibrium Approach to Adjustment Policy" Mimeo

4. OECD Åsa Johansson, Christopher Heady, Jens Arnold, Bert Brys and Laura Vartia 2008 ,Tax and economic growth” Economics Department, Working Papers nr 620

5. Parry, C.D.H. (1997). Alcohol misuse and public health: A 10-point action plan. Policy Brief No1, February 1997. South African Medical Research Council. Available [online] http://www.mrc.ac.za/policybriefs/6polbrief1997.htm

6. Penu, D. „Indirect Taxes in Romania - an Econometric Analysis”, Academic Journal of Economic Studies, Vol. 2, No.1, March 2016, pp. 121-128, ISSN 2393-4913, ISSN On-line 2457-5836

7. Single, E., Robson, L, Xie, X. and Rehm, J. (1998). "The Economic Costs of Alcohol, Tobacco and Illicit Drugs in Canada, 1992". Addition 93: 991-1006. 
Todor S.P., Ghiur R., Brezeanu P., Dumiter F., Boiță M. (2017)

The degree of compliance based on excise duties in Romania between 2002 and 2015

8. Sorensen, P.B (1998), "Recent Innovations in Nordic Tax Policy: from the Global Income Tax to the Dual Income Tax", in: Tax Policy in the Nordic countries, Macmillan Press.

9. Van As, S. 2004. "The taxing issue of alcohol abuse. Establishing an alcohol injury fund" Science in Africa, January 2004. Available [online]: www.scienceinafrice.co.za. 